\title{
Titanium bioactivity surfaces obtained by chemical/electrochemical treatments
}

\author{
Bruno Leandro Pereira ${ }^{1}$, Paola Tummler ${ }^{2}$, \\ Cláudia E. B. Marino ${ }^{3}$, Paulo César Soares ${ }^{4}$, Neide K. Kuromoto ${ }^{5}$
}

\author{
${ }^{1}$ Laboratório de propriedades nano mecânicas-LabNano - PIPE/UFPR, CP: 81530-900 Curitiba, PR \\ e-mail: brn17@hotmail.com \\ ${ }^{2}$ PGMEC/UFPR, CP: 81530-900 Curitiba, PR; e-mail: paola.t.2009@gmail.com \\ ${ }^{3}$ Departamento de Engenharia Mecânica/ UFPR, CP: 81530-900 Curitiba, PR; claudiamarino@ufpr.br, \\ ${ }^{4}$ Engenharia Mecânica/ PUC, Curitiba, PR; pcsoaresjr@yahoo.com \\ ${ }^{5}$ Departamento de Física/UFPR, Curitiba, PR.; kuromoto@ fisica.ufpr.br
}

\begin{abstract}
There are various surface treatments used to modify titanium surfaces to render it bioactive. In this study commercially pure titanium surfaces (cp Ti), grade 2 were modified by acid etching (AE) and anodic oxidation $(\mathrm{OA})$ in order to evaluate the bioactivity in vitro of these surfaces using the simulated body fluid (SBF). The AE was realized using a mixture of acids and AO using 1 mol. $\mathrm{L}^{-1}$ sulfuric acid. The anodic films were obtained under potentiostatic mode, during 60s using as anode a bar of titanium. All the surfaces that means cp Ti, AE and AO were analyzed concerning to morphology, rugosity, structural changes before in vitro bioactivity tests. It was observed by scanning electron microscopy (SEM) that all surfaces presented different morphologies: those with $\mathrm{AE}$ showed a surface with peaks and rounded valleys, with $\mathrm{Ra}=(564 \pm 80) \mathrm{nm}$, the oxidized surfaces with sulfuric acid showed a morphology with small pores uniformly distributed over the surface and $\mathrm{Ra}=(177 \pm 0,02) \mathrm{nm} . \mathrm{X}$-rays diffraction results showed the presence of titanium hydride on the samples with $\mathrm{AE}$ and the anatase and rutile phases on the anodic films after heat treatment at $600^{\circ} \mathrm{C} / 1 \mathrm{~h}$. Bioactivity tests in vitro using $\mathrm{SBF}$ at $37^{\circ} \mathrm{C}$ showed that small aggregates containing $\mathrm{Ca}$ and $\mathrm{P}$ were observed on surfaces with AE after 30 days soaked in SBF and the surfaces oxidized were fully coated with an apatite layer, identified by SEM.
\end{abstract}

Keywords: Titanium, Anodic oxidation, Bioactivity, acid etching.

\section{INTRODUCTION}

The titanium (Ti) and Ti alloys are broadly used as dental screws and orthopedic implants due low tendency to corrosion, allied to their good mechanical strength biocompatibility and high osseointegration rate $[1,2]$. $\mathrm{Ti}$ and its alloys are generally defined as bioinert materials, due to the lack of direct chemical bonding between the bone tissues and the implant [3].

To enhance the anchoring power of the osteoblasts between implant and human body in way to accelerate the apatite nucleation, surface modifications are performed on titanium surface [4-5]. Among the surface treatments has been highlighted acid etching and anodic oxidation. Both treatments results in rough morphology. Anodic oxidation technique presents some advantages such as easily well-adhered oxide film deposited on titanium surface through an electrochemical process. Porous and roughness films can be formed by applying high voltage to produce dielectric breakdown [6-12]. Extensive research in titanium shows that the morphology, surface chemistry, roughness, rutile and anatase phases significantly influences the apatite-inducing ability [13-18]. The titanium bioactivity can be evaluated using simulate body fluid (SBF) [8]. According to Kokubo and Takadama [8], a surface is bioactive if an apatite layer is formed at the Ti surface soaked in SBF at $37^{\circ} \mathrm{C}$ during several days. Thus, when the implant is soaking in the body fluid (pH 7.4) the interaction of the bioactive surface and SBF begins, giving origin to Ti-OH groups and the surface becomes slightly negative charged. The negative surface attracts $\mathrm{Ca}^{2+}$ ions from SBF solution and forms calcium titanate on the Ti surface [6-7], which acts as the nucleation point for apatite deposition.

Thus, in this study the bioactivity in vitro of titanium surfaces modified by chemical (acid etching) and electrochemical process (anodic oxidation) was evaluated in simulated body fluid (SBF) [8]. 


\section{MATERIALS AND METHODS}

Titanium commercially pure (grade 2) samples were sanded with grade 300 and $400 \mathrm{SiC}$ papers, and washed in pure acetone, isopropanol and distilled water. Subsequently, the samples were dried at $40^{\circ} \mathrm{C}$ during 24 hours.

The acid etching (AE) were realized using a mixture of two acids. For the anodic oxidation (AO) it was used an $1 \mathrm{Mol}^{-1} \mathrm{~L}^{-1} \mathrm{H}_{2} \mathrm{SO}_{4}$ electrolyte under pontenciostatic mode applying $160 \mathrm{~V}$, during $60 \mathrm{~s}$, using as anode a bar of titanium. After $\mathrm{AO}$ process, some samples were heat treated at $600^{\circ} \mathrm{C}$ (rate of $5^{\circ} \mathrm{C} / \mathrm{min}$ ) during $1 \mathrm{~h}$ and cooled slowly until reach the room temperature. The bioactivity surfaces were evaluated using Kokubo's SBF [8] (pH 7.4), during 30 days at $37^{\circ} \mathrm{C}$. The SBF is a solution that mimics the body fluid and that ionic concentrations are very close to the ionic concentrations of blood plasma, except the carbonate ions quantitate.

The morphology of the films, before and after soaked in SBF, was observed using a scanning electron microscopy (SEM) (Jeol JSM-6360LV). The average surface roughness (Ra) was obtained using a perfilometer (Veeco Dektak 150). The crystalline phases were analyzed using X-ray diffractometer (Shimadzu XRD7000 ) using Bragg Brentano geometry, $40 \mathrm{kV}, 20 \mathrm{~mA}$ and radiation $\mathrm{Cu} \mathrm{K} \alpha$. XRD data was investigated using the Crystallographica software.

\section{RESULTS AND DISCUSSION}

The figure 1.a shows the Ti surface after acid etching process. The SEM image shows a surface with many round craters. The elements present on this surface is showed in EDS spectrum (fig 1.b), where oxygen is not observed, only Ti. The ausence of $\mathrm{O}$ is due to acid etching.

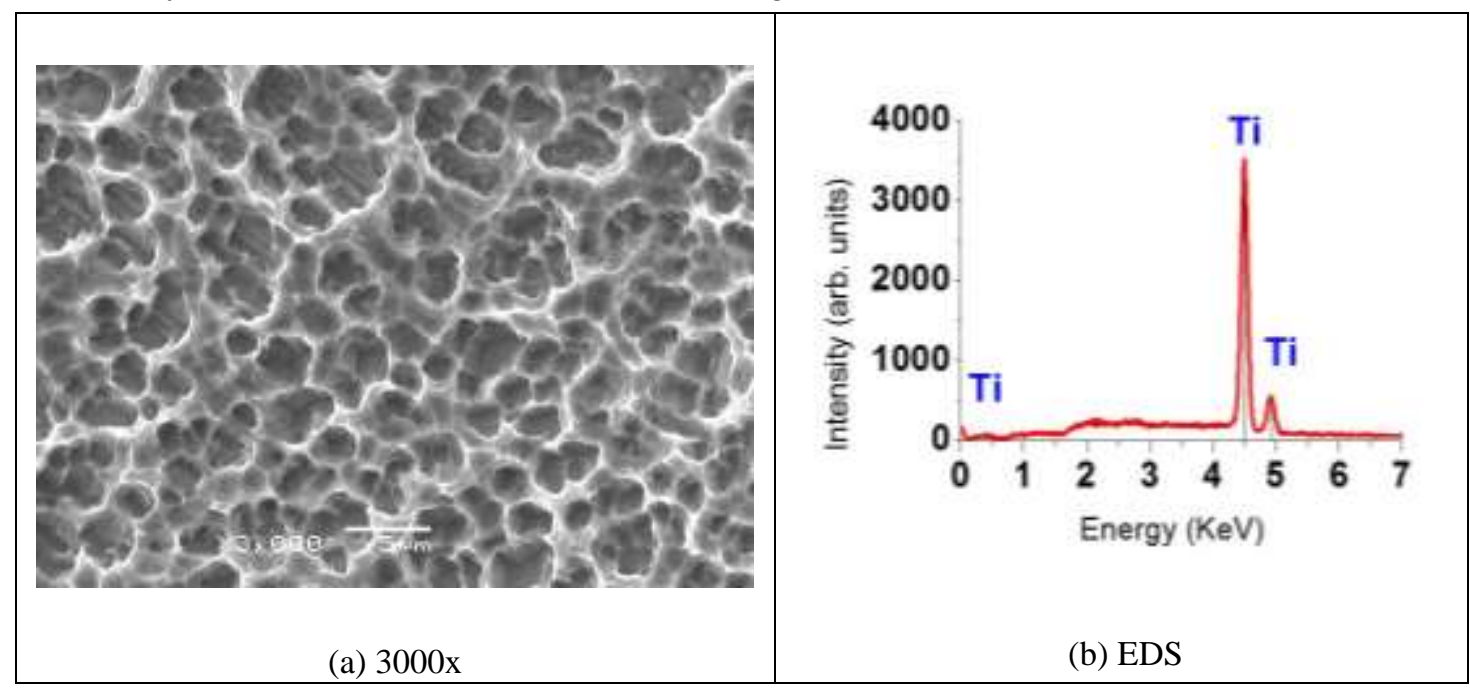

Figure 1: Titanium surface morphology after acid etching (a), and EDS spectrum identifying the elements present on the surface (b).

The morphology of the sample is changed after OA process with heat treatment as seen in figure 2.a. it can be observed structures with small pores uniformly distributed on all surface. The EDS analysis identifies the presence of the $\mathrm{Ti}$ and $\mathrm{O}$ on the anodic film (fig. 2.b). 


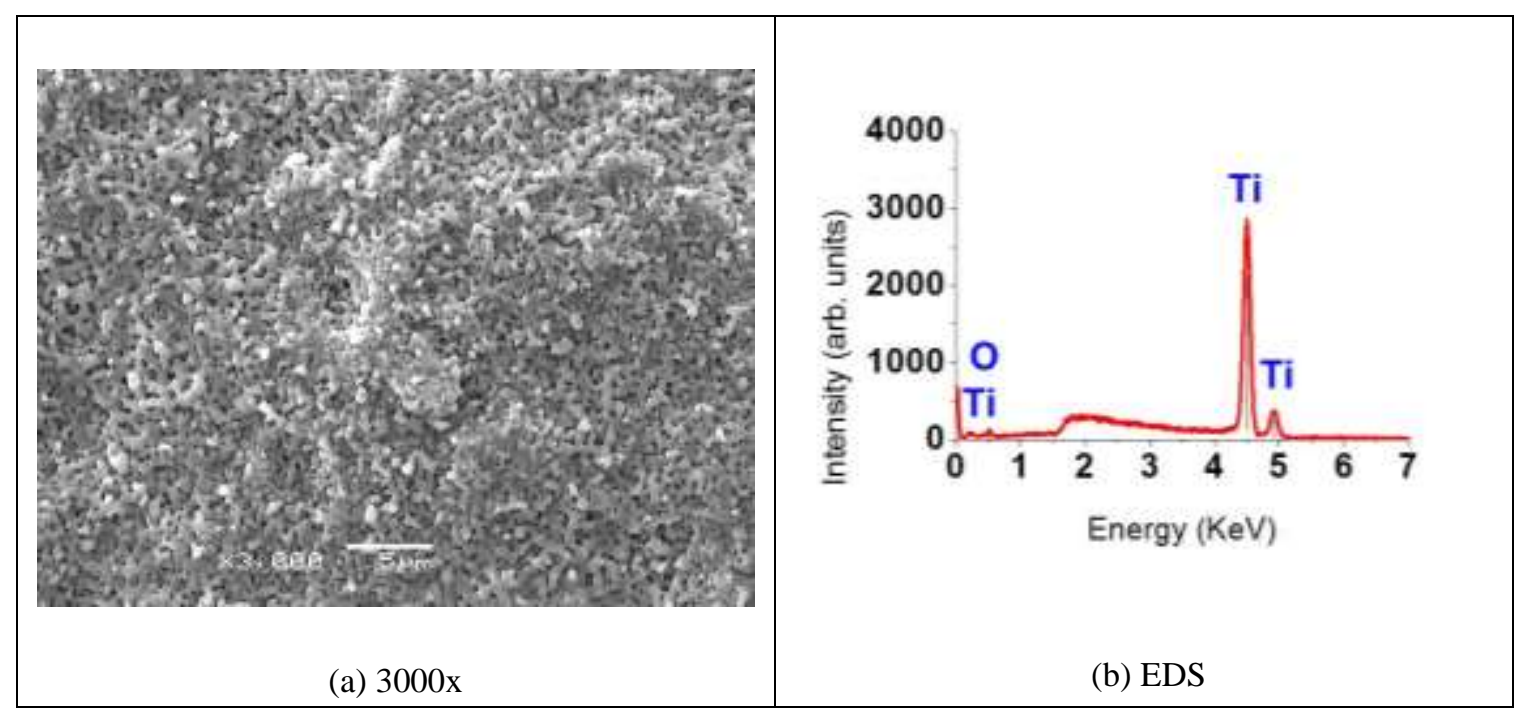

Figure 2: Ti Surface morphology after anodic oxidation in $1 \mathrm{~mol} . \mathrm{L}^{-1}$ sulfuric acid electrolyte (160V- 60s) plus heat treatment (a) with the respective EDS (b).

The results concerning to rugosity measurements are showed in table 1 . It can be observed that the rugosity values increased with the AE. According to Curtis et.al, the rugosity is an important parameter in the orientation of the cells in bone osseointegration process once the contact area is increased [18], and the rugosity affects adhesion strength of apatite layer grown over treated surface [19].

Table 1: Rugosity (Ra) measurements on the Ti surface with different treatments.

\begin{tabular}{l|l|l}
\hline SAMPLE & RUGOSITY & UNIT \\
\hline Grounded $\mathrm{Ti}$ & $288 \pm 0.04$ & nanometers $(\mathrm{nm})$ \\
\hline Acid etching & $564 \pm 0.08$ & nanometers $(\mathrm{nm})$ \\
\hline Anodic oxidation + heat treatment & $177 \pm 0.02$ & nanometers $(\mathrm{nm}))$ \\
\hline
\end{tabular}

The X-ray diffraction results are showed in figure 3. The titanium hydride peaks were identify on the acid etching surface (black line - b) and the phases of anatase and rutile on the oxide layer with AO+ HT (green line - a). According to Yang et al. the apatite-forming ability of rutile on the anodically oxidized titanium might come from the orientation of rutile to the $\left(\begin{array}{lll}1 & 0 & 1\end{array}\right)$ crystal plane. Due to the dimensions of the cells, the structure of rutile $\left(\begin{array}{lll}1 & 0 & 1\end{array}\right)$ match to the structure of apatite $\left(\begin{array}{llll}0 & 0 & 0 & 4\end{array}\right)\left[\begin{array}{ll}13 & \text {. }\end{array}\right]$ 


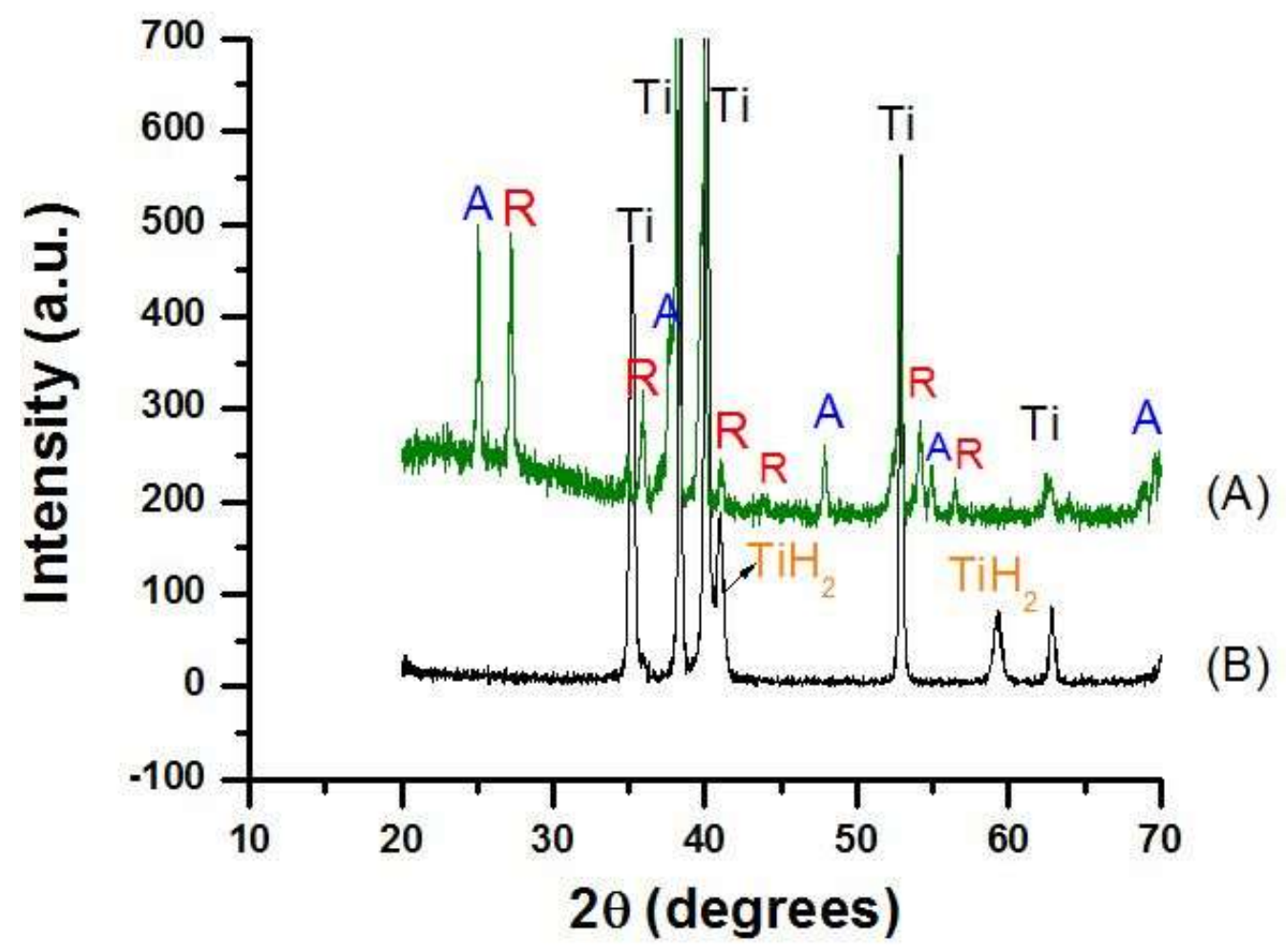

Figure 3: XRD patterns of (A) Anodic oxidation in $\mathrm{H}_{2} \mathrm{SO}_{4} 1 \mathrm{Mol} . \mathrm{L}^{-1}, 160 \mathrm{~V}$, during $60 \mathrm{~s}$, followed by heat treatment (B) Acid etched titanium surface. $\mathrm{A}=$ anatase $\mathrm{R}=$ rutile $\mathrm{TiH}_{2}=$ titanium hydride.

After soaked in SBF during 30 days at $37^{\circ} \mathrm{C}$, the samples was evaluated using SEM, EDS and x-ray diffraction. In the acid etching surface, it was observed a small precipitates nucleated on the porous surface (figure 4a-c). The EDS analysis showed that these precipitates contain $\mathrm{Ca}$ and P (fig. 4d).

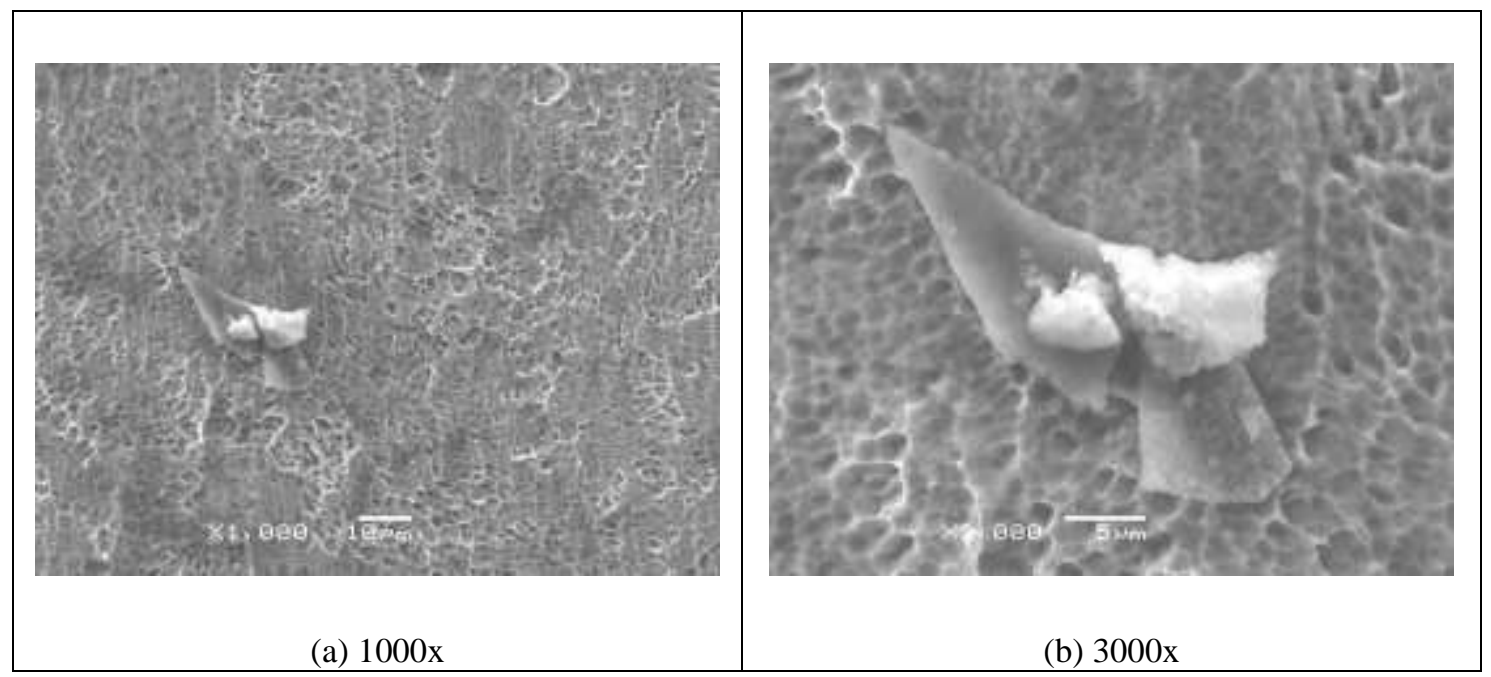




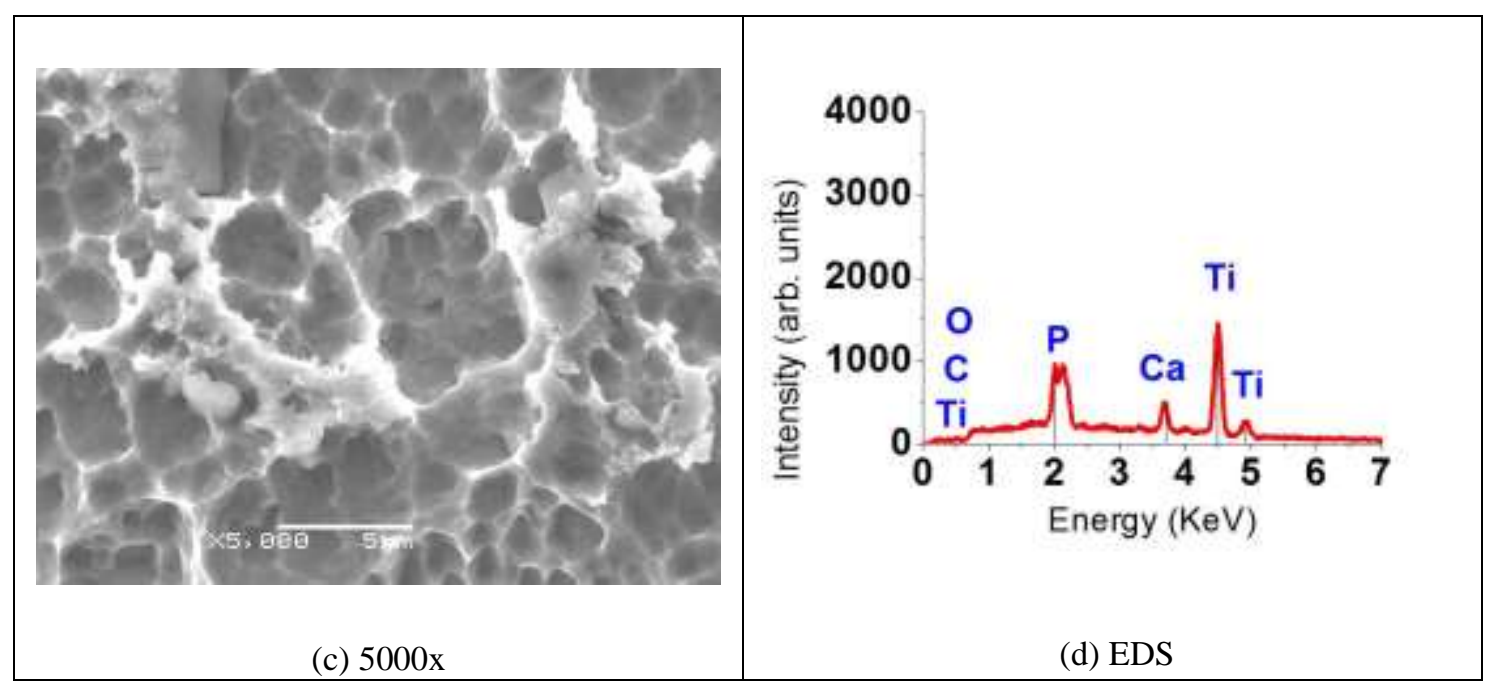

Figure 4: Surface morphology of acid etching in titanium, after 30 days soaking with the respective EDS.

SEM images of the anodized surface soaked in SBF showed a new layer covering the entire surface (fig. 5). The EDS results indicated the presence of the $\mathrm{Ca}$ and $\mathrm{P}$ in this layer. This layer corresponds to apatite, as identified by X-ray diffraction technique, showed in figure 6. According to Kokubo, a surface may be considered bioactive, when an apatite layer grows on the surface when soaked in SBF [8]. Nucleation of apatite occurs from the consumption of $\mathrm{Ca}$ and $\mathrm{P}$ ions that are in the $\mathrm{SBF}$ solution. The responsible for the nucleation start process are the Ti-OH groups on the $\mathrm{TiO}_{2}$ layer. These groups exhibit amphoteric character when they are in different $\mathrm{pH}$ range 5-6 (isoelectric point) [4]. Thus, when soaking in the SBF (pH 7.4), the surface is slightly negative charged. The negative surface attracts $\mathrm{Ca}^{2+}$, and then the $\mathrm{Ca}$ ions absorbed $\mathrm{PO}_{4}$ ions from the solution to form apatite on the surface. These results indicate that the oxidized surface is more bioactive than the acid etching surface, as was to be expected because surface features like as thicker oxide layer, with crystalline phases.

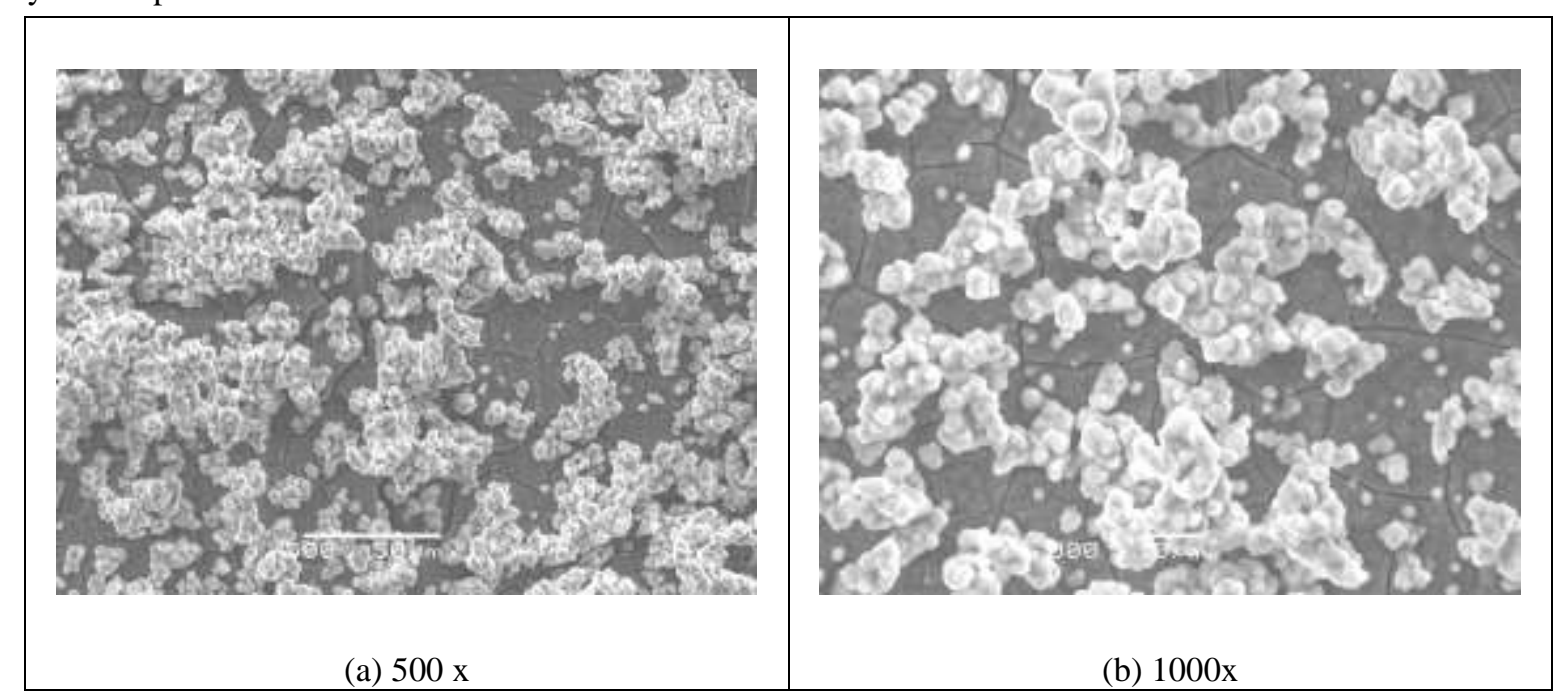




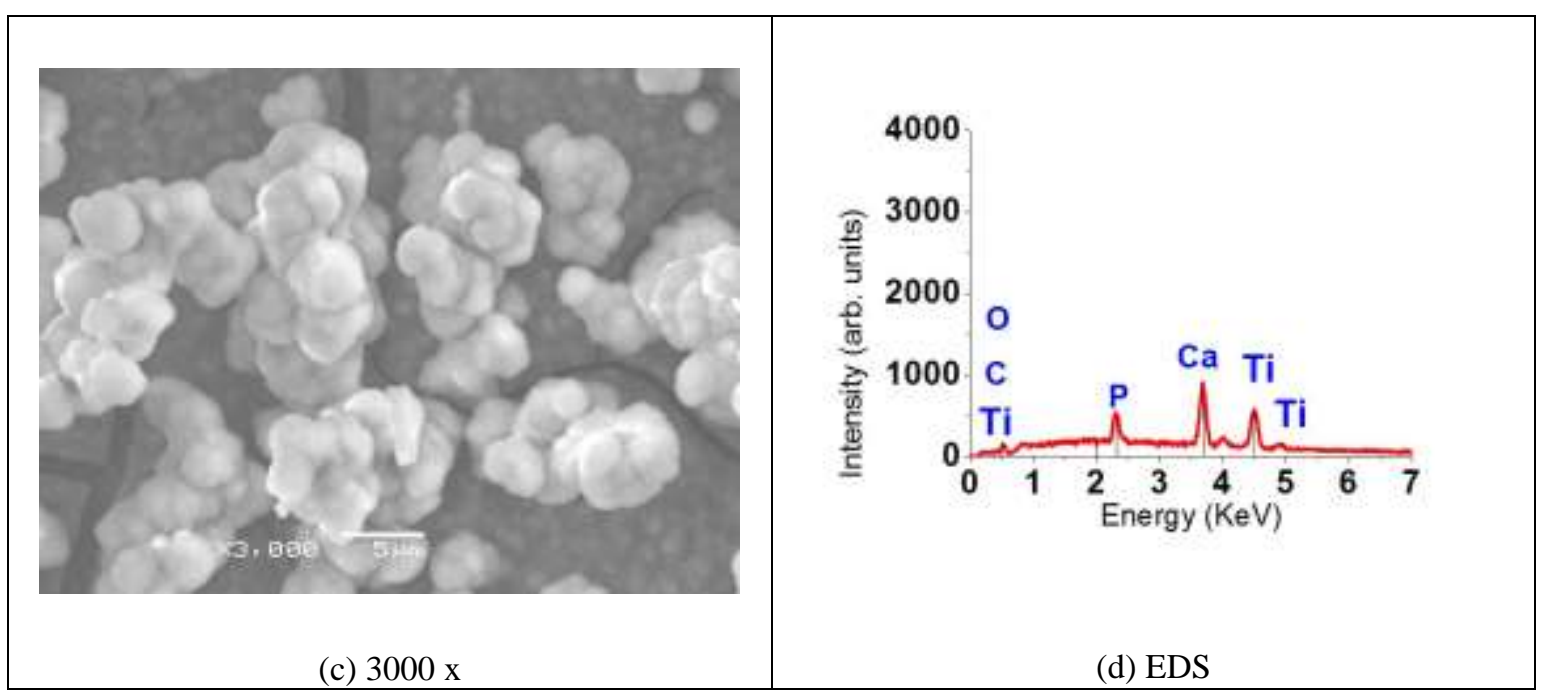

Figure 5: Surface morphology of anodic oxidation in sulfuric acid (1 Mol. $\left.\mathrm{L}^{-1}-160 \mathrm{~V}-60 \mathrm{~s}\right)$ soaking in SBF during 30 days (a-c) with the respective EDS (d).

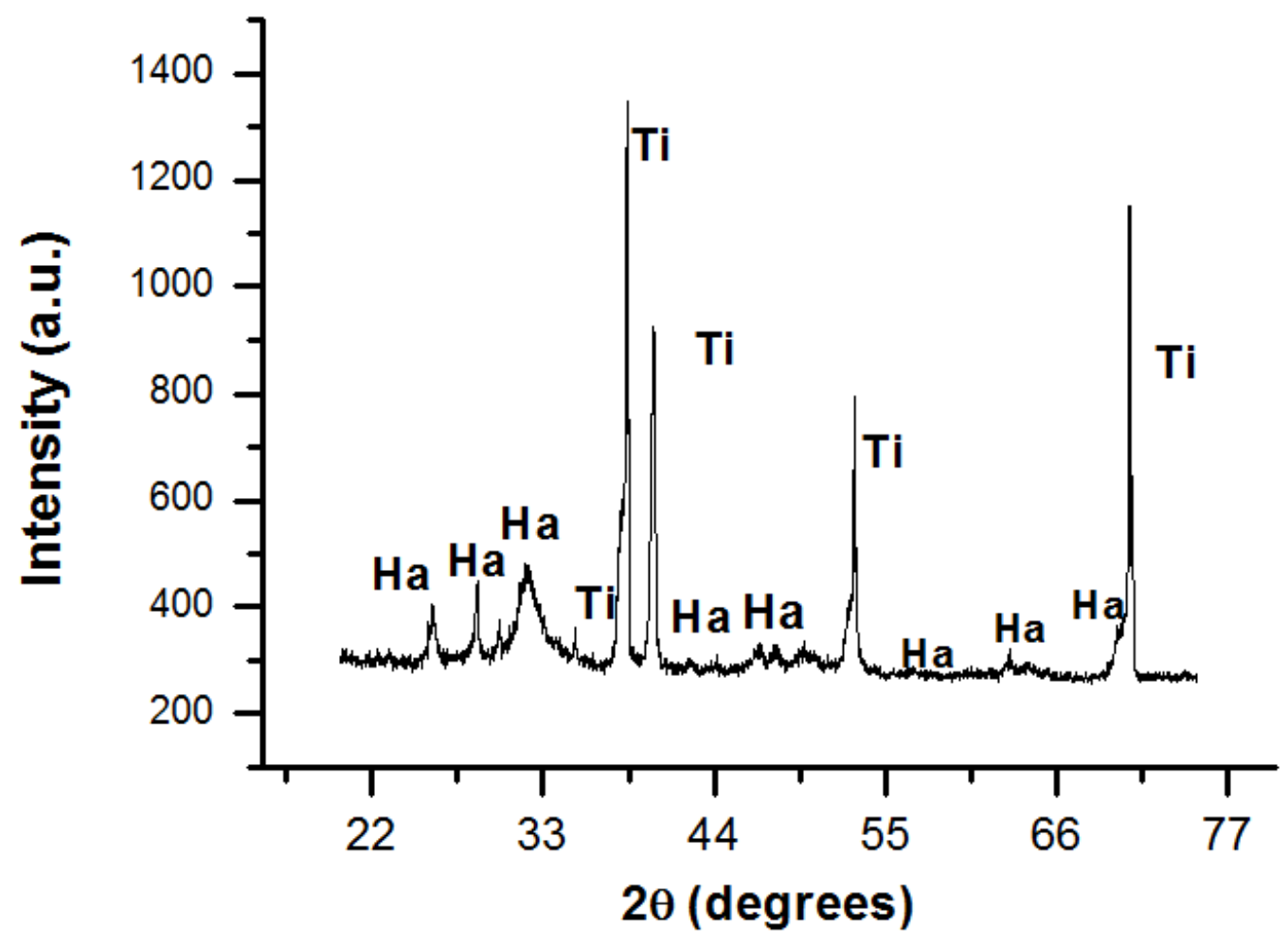

Figure 6: XRD patterns of anodized Ti surface in $\mathrm{H}_{2} \mathrm{SO}_{4} 1 \mathrm{Mol} / \mathrm{L}, 160 \mathrm{~V} / 60$ s plus heat treatment after soaked in SBF during 30 days. $\mathrm{Ha}=$ hydroxyapatite $\mathrm{Ti}=$ titanium.

\section{CONCLUSIONS}

The surface with acid etching presents round craters and the anodic film produced with sulfuric acid showed an appearance of small pores containing anatase and rutile phases. The EDS analysis shows the incorporation of the $\mathrm{P}$ ions on the anodization surface. A new layer was observed only on the oxidized surface with heat treatment after 30 days soaking in SBF. The morphology of the new layer, EDS and x-ray diffraction results showed that the layer correspond to apatite. 
PEREIRA, B.L.; TUMMLER P.; MARINO, C.B.; SOARES,P.C.; KUROMOTO, N.K. revista Matéria, v.19, n.01, pp. 16 - $23,2014$.

\section{ACKNOWLEDGMENT}

Acknowledgment to CAPES, Fundação Araucária, Centro de Microscopia- UFPR and LORXI.

\section{REFERENCES}

[1] NIINOMI, M., "Mechanical properties of biomedical titanium alloys", Materials Science and Engineering: A, v. 243, pp. 243-231, Mar. 1998.

[2] DAOOD, N. BANDEY, S.B QUASIN, H. OMAR S.A. KHAN, "Surface characterization analysis of failed dental implants using scanning electron microscopy", Acta Odontologica Scandinavica, v.69, pp. 367373, Nov. 2011.

[3] LIU X, CHU PK, DING C., "Surface modification of titanium, titanium alloys, and related materials for biomedical applications", Materials Science and Engineering: R, v.47 pp. 49-121, Dec. 2004.

[4] X.J WANG , Y.C. LI , J.G. LIN , Y. YAMADA , P.D. HODGSON, C.E. WEN, "In vitro bioactivity evaluation of titanium and niobium metals with different surface morphologies", Acta Biomaterialia, v.4, pp. $1530-1535$, Sept. 2008.

[5] CUI, X., KIM, H.M., KAWASHITA, M., WANG, L., XIONG, T., KOKUBO, T., NAKAMURA, T., "Preparation of bioactive titania films on titanium metal via anodic oxidation". Dental Materials, v. 25, n.4, pp. 80-86, Jan. 2009

[6] ROHANIZADEH, R., SADEQ, MA. LEGEROS, RZ. , "Preparation of different forms of titanium oxide on titanium surface: effects on apatite deposition", Journal of Biomedical Materials Research, v. 71 A, n.2, pp. 343 -352, Sep. 2004.

[7] TAKADAMA, H, KIM, HM, KOKUBO, T, NAKAMURA, T., "XPS study of the process of apatite formation on bioactive Ti-6Al-4V alloy in simulated body fluid". Science and Technology of Advanced Materials, v.2, n.2, pp.389-96, Jun. 2001.

[8] KOKUBO, T., TAKADAMA, H. "How useful is SBF in predicting in vivo bone bioactivity?" Biomaterials, v.27, n.15, pp. 2907 - 2915, May 2006.

[9] CHEN, Z.X., TAKAO, W.X., MATSUBARA, T., REM, L.M., "Surface characteristics and in vitro biocompability of titanium anodized in a phosphoric acid solution at different voltages, "Biomedical Materials, v.4, n.6, 0650032009, October 2009.

[10] PARK,T., CHOE, H., BRANTLEY, W.A., "Bioactivity evaluation of porous TiO2 surface formed on titanium in mixed electrolyte by spark anodization", Surface and Coatings Technology, v.235, pp. 706-713, Nov. 2013.

[11] SOUZA, G.B., LIMA, G.L., KUROMOTO, N.K., SOARES, P.C., LEPIENSKI, C.M., FOESTER, C.E., MIKOWSKI, A., "Tribo-mechanical characterization of rough, porous and bioactive Ti anodic layers", Journal of Materials Processing Technology, v.4, n.2, pp. 796-806, Jul. 2011.

[12] SZESZ, E.M., PEREIRA, B.L., KUROMOTO, N.K., MARINO, C.E.B., SOUZA, G.B., SOARES, P.C., "Electrochemical and morphological analyses on the titanium surface modified by shot blasting and anodic oxidation processes", Thin Solid Films, v.528, n.16, pp. 163-166, Jan. 2013.

[13] SONG, H.J., PARK, S.H., JEONG, S.H., PARK, Y.J., "Surface characteristics and bioactivity of oxide films formed by anodic spark oxidation on titanium in different electrolytes", Journal of the Mechanical Behavior of Biomedical Materials, v.209, n.2, pp. 864-870, Jan. 2009.

[14] Zhu, X., KIM, K.H., JEONG, Y., "Anodic oxide films containing Ca and P of titanium biomaterial”, Biomaterials, v.22, n.16, pp. 2199-2206, August 2001.

[15] YANG, B., UCHIDA, M., KIM, H.M., ZHANG, X., "Preparation of bioactive titanium metal via anodic oxidation treatment", Biomaterials, v. 25, n.6, pp.1003-1010, March 2004.

[16] HEON-SEOK, H., CHANG-WHE, K., YOUNG-JUM, L., MYUG-JOO, K., "Surface characteristics of anodic oxidized titanium according to the pore size", Journal of Korean Academy of Prosthodontics, v.44, n.3, pp.343-357, Jan. 2006.

[17] IWAYA, Y., MACHIGASHIRA, M., KAMBARA, K., MIYAMOTO, M., NOGUSHI, K., IZUMPI, Y., BAN, S., "Surface Properties and Biocompability of Acid-etched Titanium", Dental Materials Journal, v.27, n.3, pp.415-421, Mar. 2009. 
PEREIRA, B.L..; TUMMLER P.; MARINO, C.B.; SOARES,P.C.; KUROMOTO, N.K. revista Matéria, v.19, n.01, pp. 16 - 23, 2014.

[18] CURTIS, A., WILKINSON, C., “Topographical control of cells”, Biomaterials, v.18, n.24, pp.15731583, Dec. 1997.

[19] APARICIO, C., RODRIGUEZ, D., GIL, F. J., "Variation of roughness and adhesion strength of deposited apatite layers on titanium dental implants", Materials Science and Engineering: C, v.24, pp.320-324, 2011. 